İş ve İnsan Dergisi I The Journal of Human and Work

Y1l | Year: Nisan | April 2018

Cilt-Sayı | Volume-Issue: 5 (1)

ss I pp: $1-17$

doi: 10.18394/iid.359726

e-ISSN 2148-967X

http://dergipark.gov.tr/iid/

Derleme Makalesi

\title{
İş Güvencesizliğinin Etkileri: Temel Yaklaşımlar ve Olumsuz Etkileri Düzenleyici Faktörler Üzerine Bir Derleme
}

\author{
The Effects of Job Insecurity: A Review on Fundamental Approaches and Moderators \\ of Negative Effects
}

\author{
Ümran Yüce-Selvi a, Nebi Sümer ${ }^{*}, b$
}

MAKALE BİLGİSİ

Anahtar Kelimeler:

İş güvencesizliği, çalışan iyilik hali, düzenleyici değişkenler, tampon etkisi

\section{Tarihler:}

Geliş 30 Kasım 2017

Düzeltme geliş 09 Ocak

2018

Kabul 02 Mart 2018

\section{ARTICLE INFO}

\section{Keywords:}

Job insecurity, employee

well-being, moderator

variables, buffering effect

\section{Article history:}

Received 30 November 2017

Received in revised form 09

January 2018

Accepted 02 March 2018

\begin{abstract}
ÖZ
Mevcut işin gelecekteki devamlılığ ile ilgili duyulan endişe olarak tanımlanan iş güvencesizliği günümüz çalıșma hayatındaki en önemli stres kaynaklarından biridir. Araştırma bulguları ișin devamlılı̆̆ına dair duyulan endişenin çalı̧̧anların genel iyilik hali, psikolojik ve fiziksel sağllğg ve iş yaşamı üzerindeki olumsuz etkisine işaret etmektedir. Bu derleme çalışmasında iş güvencesizliği algısinin çalışanlar üzerindeki etkisinin ötesine geçilerek, söz konusu etkiyi düzenleyen faktörlere odaklanılmış ve bu konudaki çalışmalar sistematik olarak incelenmişstir. Bu kapsamda geçmiş çalışmalar taranmıs, ilgili temel kuramlar, modeller ve yaklaşımlar özetlenmiş, demografik ve bireysel özelliklerin, iș ve örgüt ile ilgili etmenlerin ve kültürel değerlerin iş güvencesizliğinin çalı̧̧anlar üzerindeki etkilerini düzenleyici (moderatör) rolleri irdelenmiştir. Derlenen çalışmalar bir tablo içinde sunulmuş, bulguların doğurguları yorumlanmış ve gelecek araştırmalar için önerilerde bulunulmuştur.
\end{abstract}

a İletişim Kurulacak Yazar, Arş. Gör., Fen Edebiyat Fakültesi, Psikoloji Bölümü, Eskişehir Osmangazi Üniversitesi, Eskişehir, Türkiye. E-mail: umrannyuce@gmail.com.ORCID:0000-0001-7435-7510

*,b Prof. Dr., Fen Edebiyat Fakültesi, Psikoloji Bölümü, Orta Doğu Teknik Üniversitesi, Ankara, Türkiye. E-mail: nsumer@metu.edu.tr. ORCID: 0000-0002-7460-4515 
"Hem işsizler hem de işten atılma korkusuyla çalışanlar, gerçekte kendilerinin sorumlu olmadiğ (ekonomik ya da politik) bir suçun cezasını işkence altında çeken unutulmuş masum mahkûmlar gibidir. Ne yaşadıkları, ne hissettikleri bilinmez, çı̆̆lıkları duyulmaz."

Sümer, Solak, \& Harma, 2013, s. 15.

\section{GİRIŞ}

Küresel düzeyde, 1970'li y1llarda başlayan ve günümüze kadar devam eden ekonomik krizler ve uygulamaya koyulan neo-liberal politikalar, çalışma yaşamında önemli bazı değişim ve dönüşümlere yol açmıştır. $\mathrm{Bu}$ değişim ve dönüşümler karşısında örgütler, varlıklarını sürdürebilmek, rekabet güçlerini koruyabilmek ve kar oranlarını yükseltebilmek amacıyla bazı önlemlere başvurmuştur. Küçülmeye gitme, yeniden yapılanma, şirket kapanması, şirket birleşmesi, özelleştirmeler ve istihdamda esneklik politikaları (örn. çalışanlar ile geçici iş sözleşmesi imzalamak, taşeron işyerinde çalışmak), örgütlerin başvurduğu yollardan bazılarıdır. Çalışma yaşamındaki bu değişim ve dönüşümlerin çalışanlar üzerindeki yansıması ise artan işsizlik oranları; halen bir işte çalışmakta olanlar için ise her y1l daha da artan işi kaybetme korkusu olmuştur (Cooper, Dewe \& O’Driscoll, 2001; Hartley, Jacobson, Klandermans \& Van Vuuren, 1991; Sümer vd., 2013; Sandıkç1, 2009; Sverke, Hellgren \& Naswall, 2002). Türkiye İstatistik Kurumu (TÜİK) Ekim 2017 işgücü istatistikleri raporunda açıklanan resmi işsiz sayısı (3 milyon 287 bin kişi) ve işsizlik oranına $(\% 10,3)$ bakıldığında, ülkemiz için de işsizliğin ve iş güvencesizliğinin üzerinde önemle durulması gereken bir konu olduğu açıktır.

İşsizlik ve iş güvencesizliği hem nedenleri hem de sonuçları bakımından benzerlik göstermekte, bazen de iç içe geçmektedir. İşsiz kalma korkusu yaşayan çalışanlar, işsizlerin yaşadığına benzer sosyal ve psikolojik sorunlar yaşamaktadır. Yani sadece işsiz olmak değil, her an işsiz kalabileceğini düşünmek de çalışanlar üzerinde olumsuz sonuçlar doğurmaktadır (Sandıkçı, 2009). Ancak işsizlik ile karşılaştırıldığında iş güvencesizliği ve etkileri çok daha az araştırılan bir konu olmuştur. Oysa iş güvencesizliği gelecek ile ilgili uzun süreli belirsizlik ve tehdit algısı içermesi bakımından işsizliğe kıyasla daha olumsuz sonuçlar doğurma riski taşımaktadır (Sümer vd., 2013).
Türkçe yazında iş güvencesizliğinin etkileri ile ilgili az sayıda çalışma vardır. Bu çalışmalar genel olarak iş güvencesizliği algısının çalışanların psikolojik sağlığı (bkz. Dursun \& Bayram, 2013) ve bazı örgütsel değişkenler üzerindeki etkilerine odaklanmıştır (bkz. Karacaoğlu, 2015; Poyraz \& Kama, 2008). Özetle, Dursun ve Bayram (2013) iş güvencesizliğinin çalışanların kaygı düzeyleri üzerine etkisini araştırmış, algılanan iş güvencesindeki azalmasının çalışanların kaygı düzeyini arttığını bulmuştur. Karacaoğlu (2015) iş güvencesizliği ile işten ayrılma niyeti arasındaki ilişkiyi incelemiş, iş güvencesizliği ile işten ayrılma niyeti arasında yüksek düzeyde ve olumlu yönde bir ilişki bulmuş ve iş güvencesizliğinin işten ayrılma niyetini orta düzeyde açıklama gücüne sahip olduğunu göstermiştir. Poyraz ve Kama (2008) ise iş güvencesinin, iş tatmini, örgütsel bağlılık ve işten ayrılma niyeti üzerindeki etkilerini araştırmış, iş güvencesi ile iş tatmini ve örgütsel bağlılık arasında olumlu yönde, iş güvencesi ile işten ayrılma niyeti arasında ise olumsuz yönde bir ilişki olduğunu bulmuştur.

İş güvencesizliği Batı ülkelerinde de işsizliğe oranla daha az çalışılmış, ancak son 30 yılda belirli bir birikime ulaşmıştır (De Witte, 2005). İş güvencesizliğinin etkileri konusundaki ilk metaanalizi Sverke vd. (2002) 72 çalışma üzerinde gerçekleştirmiş̧tir. Meta-analiz bulguları, iş güvencesizliği algısının çalışanların fiziksel ve psikolojik sağlığını, işe ve örgüte yönelik tutumlarını ve çalıştıkları kurumları ile olan ilişkilerini olumsuz yönde etkilediğini göstermiştir. Sverke vd. (2002)' nin bulguları, görece daha yeni olan ve görece daha geniş bir veri tabanı kullanılarak Cheng ve Chan'ın (2008) metaanalizinde de desteklenmiştir.

İlgili konudaki bu iki temel meta-analiz çalışması 1şığında, mevcut çalışmada iş güvencesizliği algısının çalışanların iyilik hali (well-being) üzerindeki etkisi ve bu etkiyi düzenleyen değişkenleri (moderators) kapsayan bir derleme yapılması amaçlanmıştır. İyilik hali, başta psikoloji olmak üzere sosyal bilim alanlarında çok sayıda araştırmacının üzerinde çalıştığ 1 bir konudur ve "bir kişinin yaşam kalitesinin kendi seçtiği ölçütlere göre değerlendirilmesi” (Shin \& Jonhson, 1978: 478) olarak tanımlanmaktadır. $\mathrm{Bu}$ tanımı temel alarak bu derleme çalışmasında yaşam doyumu, iş doyumu, fiziksel ve psikolojik sağlık değişkenleri, iyilik halinin göstergeleri olarak kabul edilmiş, söz konusu değişkenleri bağımlı değişken olarak ele alan çalışmalar incelenip, mevcut derleme kapsamına alınmıştır. 


\section{KAVRAMSAL ÇERÇEVE}

\section{1. İş güvencesizliği Olgusu}

İş güvensizliği iş yaşamındaki en önemli stres kaynaklarından birisi olarak değerlendirilmekte (Ashford, Lee \& Bobko, 1989; De Witte, 1999; Hartley vd., 1991) ve yaygın olarak işin gelecekteki devamlılığı ile ilgili duyulan endişe (Sverke vd., 2002) olarak tanımlanmaktadır. Ancak ilgili yazın incelendiğinde iş güvencesizliğinin çok farklı şekillerde tanımlandığ 1 görülmektedir. Temel olarak iş güvencesizliğinin tanımlanmasında öznel (algılanan) ve nesnel (objektif) iş güvencesizliği, bilişsel ve duygusal iş güvencesizliği, nitel ve nicel iş güvencesizliği olmak üzere üç yaklaşım ortaya çıkmaktadır. Nesnel iş güvencesizliği, işgücü piyasasının ve bireyin çalışma koşullarının özelliklerinden kaynaklanan nesnel bir durumu yansıtmaktadır. Yüksek işsizlik oranları, kayıt dışı ve kısmi süreli istihdam, şirketlerin küçülmeye gitmesi, çalışanlar ile yapılan geçici iş sözleşmeleri, iş piyasasının daralması veya başka nedenlerle işten çıkarmaların artması gibi durumlar nesnel iş güvencesizliğini arttıran etmenler olarak düşünülebilir (Sümer vd., 2013). Öznel iş güvencesizliği ise, bireyin işini kaybetme korkusu neticesinde yaşadığı kaygıyı yansıtan öznel bir değerlendirmedir ve kişiden kişiye farklılıklar gösterebilir. Aynı nesnel durum karşısında iki farklı çalışanın risk algısı ve dolayısıyla da hissettiği korku ve panik farklı olabilir (Sümer vd., 2013). İş güvencesizliğinin tanımlanmasında kullanılan nesnel/öznel yaklaşımı, iş güvencesizliğinin sadece sigortasız ve güvencesiz çalışmak gibi nesnel bir değerlendirme ile sınırlandırılamayacağını, aynı zamanda çalışanların bireysel özellikleri veya diğer özelliklerden kaynaklanabilecek alg1 farklıkları da içerdiğini göstermesi açısından önemlidir.

Bilişsel/duygusal iş güvencesizliği yaklaşımı, iş güvencesizliğinin bilişsel ve duygusal öğelerine dikkat çekmektedir. $\mathrm{Bu}$ yaklaşıma göre, işini kaybetme olasılığı iş güvencesizliğinin bilişsel öğesine işaret ederken, hissedilen iş kaybı korkusu iş güvencesizliğinin duygusal öğesini açıklamaktadır (Borg \& Elizur, 1992). Diğer yandan, nicel iş güvencesizliği, çalışanın işinin gelecekteki varlığı ile ilgili kaygısını anlatmak için kullanılırken, nitel iş güvencesizliği çalışanın değer yüklediği bazı iş özelliklerinin (örn. gelir, kariyer firsatları, sosyal çevre) kaybedileceği endişesini ifade etmektedir (Hellgren, Sverke \& Isaksson, 1999).

\section{2. İş Güvencesizliğinin Çalışan Üzerindeki Etkilerini Düzenleyen Değişkenler}

Bulgular işin devamlılığına dair algılanan tehdidin farklı kişileri farklı şekillerde etkilediğini göstermiştir (örn. Cheng \& Chan, 2008; Sverke vd., 2002). Bu bulgular ile bağlantılı olarak, son yıllarda araştırma ilgisi iş güvencesizliğinin olumsuz etkilerini araştırmanın ötesine geçerek, bu etkiyi düzenleyen faktörleri anlamaya kaymıştır (Cheng \& Chan, 2008; Stiglbauer, Selenko, Batinic \& Jodlbauer, 2012). Bu bağlamda mevcut çalışma, iş güvencesizliğinin çalışanlar üzerindeki olumsuz etkilerini düzenleyen değişkenler konusunda bir derleme sunmayı amaçlamıştır.

Geleneksel olarak, iş güvencesizliğinin çalışanlar üzerindeki olumsuz etkileri stres kuramı (Lazarus \& Folkman, 1984) çerçevesinde ele alınmıştır. Bu kuram temel olarak stres-gerginlik (strain) ilişkisinde bilişsel değerlendirme süreçlerinin önemini vurgular. Stres kuramı, birincil ve ikincil değerlendirme olmak üzere iki bilişsel değerlendirme aşaması tanımlar. Birey birincil değerlendirmede yüzleştiği durumun stresli olup olmadığını ve bir tehdit içerip içermediğini değerlendirir; ikincil değerlendirmede ise, stres yaratan durum ya da mevcut tehdit ile başa çıkmasını sağlayabilecek başa çıkma seçeneklerini (örn. durumu değiştirmek, durumu kabul etmek veya kaçmak) gözden geçirir. İki aşamadan oluşan bu değerlendirme süreci sonucunda birey mevcut kaynaklarının hissedilen stres ile başa çıkabilmek için gerekli olan çaba ile örtüşmediğine karar verirse stres derinleşir, gerginlik artar ve dolayısıyla da iyilik hali hasar görür (Lazarus \& Folkman, 1984).

Mevcut işin gelecekteki devamlılığına ilişskin tehdit olarak tanımlanan iş güvencesizliği, birincil değerlendirmede bir stres ya da tehdit faktörü olarak değerlendirilebileceği için çalışanlar üzerinde olumsuz bir etki yaratacağı varsayılabilir. Ancak ikincil değerleme süreci sırasında çalışanlar tarafından göz önüne alınan bazı kişisel ve durumsal faktörler, kişilerin bu stres kaynağı ile nasıl başa çıkacağını etkileyebilir, dolayısıyla da iş güvencesizliğinin çalışan üzerindeki olumsuz etkilerini hafifletebilir ya da güçlendirebilir (Lazarus \& Folkman, 1984). İş güvencesizliği yazınında bu noktadan hareket eden çalışmalar, bazı demografik özelliklerin ve diğer bireysel faktörlerin, iş ve örgüt ile ilgili etmenlerin ve bireyin içinde bulunduğu kültürün, iş güvencesizliğinin çalışan üzerindeki etkisini şekillendirebileceğini öne sürmüştür.

\subsection{Demografik Özelliklerin İş Güvencesizliğinin Etkilerini Düzenlemedeki Rolü}

İş güvencesizliğinin çalışanları nasıl etkilediği konusunda, demografik faktörlerin düzenleyici rolü, 
yazında kayda değer sayıda araştırmanın konusu olmuştur (bkz. Cheng \& Chan, 2008; De Witte, 1999; Mauno, Ruokolainen \& Kinnunen, 2013; Sverke vd., 2002). Bu konudaki araştırmalar yaş, çalışma süresi, cinsiyet ve mesleki statü değişkenlerinin düzenleyici rolüne odaklanmış, bulgular genel olarak farklı çalışan gruplarının iş güvencesizliği algısından farklı şekilde etkilenebileceği savını desteklemiştir.

Cheng ve Chan (2008), bireysel çalışmaların sonuçlarını derledikleri meta-analiz çalışmasında, sağlık ile ilgili sonuçlar bakımından iş güvencesizliğinin yaşlıları ve daha uzun zamandır çalışanları, gençlere ve kısa süredir çalışanlara göre daha olumsuz etkilendiğini göstermiştir. Genç yaşın iş güvencesizliği algısının çalışanlar üzerindeki olumsuz etkisine karşı tampon görevi gördüğünü bulan Mauno vd. (2013) de Cheng ve Chan'ın (2008) yaş ile ilgili bulgularını desteklemiştir. Yaşça büyük olan çalışanların gençlere göre mevcut işlerine daha fazla bağımlı olabileceği düşünüldüğünde (Cheng \& Chan, 2008), yaş ile ilgili bu bulguların işlerine yüksek düzeyde bağımlı olan kişilerin iş güvencesizliği algısından daha fazla zarar göreceğini ileri süren işe bağımlı olma perspektifini (Greenhalgh \& Rosenblatt, 1984) desteklediği savunulabilir. Diğer yandan, genç yaşın iş güvencesizliğinin olumsuz etkilerini azalttığına ilişkin bulgular tutarlı değildir. Bazı araştırmalarda bu bulgunun desteklenmemiş olması (bkz. De Witte, 1999), yaşın bu ilişkideki düzenleyici rolü konusunda kesin bir sonuca varmayı zorlaştırmaktadır. Ancak, iş güvencesizliği yaşayan gençlerin, daha yaşlilara oranla, gelecekte istihdam edilebileceklerine ilişkin beklentilerinin daha yüksek olacağından görece daha az stres yaşamaları beklenebilir.

İş güvencesizliği algısının çalışanlar üzerindeki etkilerinin cinsiyete göre değişip değişmediğini araştıran çalışmalarda çelişkili sonuçlar elde edilmiştir. De Witte (1999) yaptığı derlemede, kadınlarda iş güvencesizliği algısı ile psikolojik sağlık değişkenleri arasında ilişkili bulamazken, erkeklerde iş güvencesizliği algısının sıkıntı (distress) ile olumlu yönde ve anlamlı düzeyde ilişkili olduğunu bulmuştur. De Witte, kadın ve erkek çalışanlar arasındaki bu farkı açıklamak için De Witte, De Goede ve Maassen'in (1988) rol kuramından yararlanmış, kadınların alternatif rollerinin onları iş güvencesizliğinin olumsuz etkilerine karşı koruduğunu vurgulamıştır. Diğer yandan, Cheng ve Chan'in (2008) meta-analiz çalışması bulguları, cinsiyetin iş güvencesizliği ile çalışan iyilik hali arasındaki ilişkide düzenleyici rolünü desteklememiş ve iş güvencesizliği algısının çeşitli değişkenler üzerindeki etkisinin cinsiyete bağlı olarak değişmediğini göstermiştir. Bu sonuç 1şı̆̆ında araştırmacılar De Witte (1999)'den farklı olarak iş güvencesizliğinin hem kadınlar hem de erkekler için eşit derecede stresli olduğu sonucuna varmıştır.

Diğer çalışmalar, farklı mesleki statüde (mavi/beyaz yaka) çalışan kişilerin iş güvencesizliği algısından farklı şekillerde etkilenip etkilenmediğini araştırmış, ancak anlamlı bir iş güvencesizliği algısı ve mesleki statü etkileşimi bulamamıştır (bkz. De Witte, 1999; Sverke vd., 2002). Diğer bir deyişle, geçmiş bulgular iş güvencesizliği algısının olumsuz etkilerinin çalışanların mesleki statüsünün bir fonksiyonu olarak değişmediğine işaret etmektedir. Özet olarak, yaş, görev süresi, cinsiyet ve mesleki statünün iş güvencesizliğinin etkilerini şekillendirmesi konusundaki çelişkili bulgular, demografik faktörlerin iş güvencesizliğinin çalışanlar üzerindeki etkileri konusundaki düzenleyici rolleri ile ilgili bir sonuca varmayı zorlaştırmaktadır. $\mathrm{Bu}$ nedenle, demografik faktörlerin iş güvencesizliğinin etkilerini nasıl şekillendirdiğini tam manasıyla anlayabilmek için ek araştırmalara ihtiyaç duyulmaktadır.

\subsection{Bireysel Özelliklerinin İş Güvencesizliğinin Etkilerini Düzenlemedeki Rolü}

İlgili yazında iş güvencesizliğinin çalışanlar üzerindeki etkilerini araştıran bazı çalışmaların, çalışanların bireysel özelliklerinin düzenleyici etkisine odaklandığı görülmektedir. Bu kapsamda, kişilik, düzenleme odağı ve kullanılan başa çıkma stratejileri, araştırmacıların üzerinde durduğu temel değişkenlerdir.

\subsection{Kişiliğin Düzenleyici Rolü}

Kişilik, hem stres değerlendirmesini etkileyen hem de stres ile başa çıkma stratejilerini belirleyen önemli bir faktördür (Lazarus \& Folkman, 1984). Araştırmacılar farklı kişilik özelliklerinin, insanların tehdit içeren bir durumu nasıl değerlendirdiğini ve bu durumu nasıl ele aldığını etkileyebileceğini göstermiştir (bkz. Naswall, Sverke \& Hellgren, 2005). Naswall vd. (2005) olumlu duygulanım (olumlu bir bakış açısına sahip olmak ve sosyallik Judge, Thoresen, Pucik \& Welbourne, 1999), olumsuz duygulanım (kendinin, başkalarının ve dünyanın olumsuz yönlerine odaklanmak Watson \& Clark, 1984) ve dış kontrol odağının (gelişen olaylar üzerinde bireyin çok fazla kontrolünün olmadığı algısı, Naswall vd., 2005) iş güvencesizliği algısının etkilerini düzenleyen temel değişkenler olduğunu öne sürmüştür. Bu bağlamda, düşük olumsuz duygulanım, yüksek olumlu duygulanım ve düşük diş kontrol odağına sahip olmanın iş güvencesizliği algısının çalışan iyilik hali üzerindeki olumsuz etkisini hafifleteceğini 
iddia etmiştir. Bulgular dıș kontrol odağının düzenleyici rolünü desteklemiş, yüksek iş güvencesizliği durumunda, yüksek diş kontrol odağına sahip çalışanların düşük dış kontrol odağına sahip olanlara göre iş güvencesizliğine daha olumsuz tepki verdiğini ortaya koymuştur. $\mathrm{Bu}$ bulgu, kontrol odağının çalışanların iş güvencesizliği algısına verdikleri tepkilerini etkileyen önemli bir faktör olabileceğini göstermekle birlikte yüksek dış kontrol odağına sahip çalışanların iş güvencesizliği durumunda daha fazla yardıma ihtiyaç duyabileceğine işaret etmektedir (Naswall vd., 2005).

Naswall vd. (2005) olumlu ve olumsuz duygulanımın düzenleyici etkisine destek bulamasa da Mak ve Mueller (2000) olumsuz duygulanımın iş güvencesizliği ve çalışan iyilik hali arasındaki ilişkide anlamlı bir düzenleyici olduğunu bulmuş, olumsuz duygulanım düzeyi yüksek olan çalışanların iş güvencesizliği durumunda daha fazla mağduriyet yaşadığını göstermiştir. Bu bulgu, başta olumsuz duygulanım olmak üzere bazı kişilik özelliklerinin çalışanları strese daha duyarlı hale getireceği ve bu tür kişilik özelliklerine sahip çalışanların stres altında daha fazla sıkıntı yaşayacağına işaret etmektedir (McCrae \& Costa, 1987; Watson \& Clark, 1984). Sonuç olarak, mevcut bulgular kişilik özelliklerinin iş güvencesizliğine verilen tepkileri farklılaştırabileceğini ortaya koymakta ve henüz araştırılmamış diğer kişilik özelliklerinin etkisinin araştırılmasının gerekliliğini göstermektedir.

\subsection{Düzenleme Odağının Düzenleyici Rolü}

Düzenleme odağı kuramı (DOK, Higgins, 1997) zevke yaklaşmak ve acıyı önlemek (yaklaşmakaçınma motivasyonu) için kullanılan iki bireysel düzenleme stratejisi tanımlar. Gelişme odağı (promotion focus) yaklaşma motivasyonuna dayalı olarak gelişme, ilerleme, açılım, yükselme amaç ve ihtiyaçlarıyla ilişkiyken, korunma odağı (prevention focus) kaçınma motivasyonuna dayalı olarak savunma, güvenlik, emniyette olma amaç ve gereksinimleri ile ilişkilidir. Araştırmalar, korunma odağ1 ve iş güvenliğine sahip olma arzusu arasında olumlu yönde bir ilişki olduğunu göstermiştir (Sassenberg \& Scholl, 2013). Bu bulgu kronik korunma odaklı çalışanların iş güvencesizliğine nasıl tepki vereceği sorusunu akla getirmiştir. Bu soruya odaklanan Öztürk, Karagonlar \& Emirza (2016), korunma odaklılığın iş güvencesizliği ve çalışan iyilik hali ilişkisinde anlamlı bir düzenleyici faktör olup olmadığını araştırmıştır. Bulgular beklendiği gibi korunma odaklı çalışanların iş güvencesizliğinden daha olumsuz etkilendiğini göstermiş ve kronik korunma odaklı bireylerin iş güvencesizliği durumunda daha fazla duygusal tükenmişlik yaşadığını ortaya koymuştur. Düzenleme odağının düzenleyici rolüne ilişkin bu bulgu iş güvencesizliğinin etkileri konusunda çalışanın bireysel özelliklerinin önemine bir kez daha dikkat çekmektedir.

\subsection{Başa Çıkma Stratejilerinin Düzenleyici Rolü}

İş güvencesizliğinin etkileri konusunda, bireysel özelliklerin önemini dikkate alan diğer araştırmalar bireyin yararlandığı başa çıkma kaynaklarının önemi üzerinde durmuştur. Başa çıkma kaynağı, karşılaşılan olumsuz bir durum ile başa çıkabilmek için uygun psikolojik koşulların oluşmasını sağlayan çeşitli strateji ve araçlar olarak tanımlanmaktadır (Osipow \& Spokane, 1987; Parkes, 1994). Mevcut başa çıkma kaynaklarının değerlendirilmesi, Lazarus ve Folkman'ın (1984) stres ile başa çıkma modelinin önemli bir unsurudur. Model stres faktörünün yoğunluğu ve mevcut başa çıkma kaynaklarının değerlendirilmesi arasındaki etkileşimin, bireyin stres ile nasıl mücadele edeceğini belirlediğini öne sürmektedir.

İlgili yazında, kişisel bakım (self-care, Mak \& Mueller, 2000), iyimserlik (Cheng, Mauno, \& Lee, 2014a), sosyal destek (Lim, 1996; Dekker \& Schaufeli, 1995), mevcut durumun değiştirilmesi (stresli bir durumun kişinin isteklerini karşılayacak şekilde değiştirilmesi), uzlaşma (kişinin isteklerinin mevcut duruma uyacak şekilde düzenlenmesi), değer düşürme (algı ve istek arasındaki tutarsızlığın öneminin düşürülmesi), semptomların azaltılması (iyilik hali algısının arttırılması/ daha iyi hissetme) gibi doğrudan başa çıkma stratejileri (bkz. Cheng vd., 2014b) ve kaçınma (dikkatin mevcut durumdan başka yöne çevrilmesi, bkz. Cheng vd., 2014b; Mantler, Matejicek, Matheson \& Anisman, 2005), iş güvencesizliği ile iyilik hali arasındaki ilişkiyi düzenleme potansiyeli olan başa çıkma stratejileri olarak öne sürülmüştür. Bulgular kişisel bakımın anlamlı bir düzenleyici faktör olduğunu göstermiş, kişisel bakım düzeyi düşük olan çalışanların iş güvencesizliği durumunda daha fazla fiziksel gerginlik yaşadığını ortaya koymuştur. İyimserliğin söz konusu ilişkide anlamlı bir düzenleyici etkiye sahip olmadığı görülmüş, sosyal desteğin rolüne ilişkin olarak ise çelişkili bulgulara ulaşılmıştır. Bazı çalışmalar yüksek düzeylerde iş arkadaşı, aile ve arkadaş desteğine sahip olan çalışanların iş güvencesizliğinden daha az etkilendiğini bulurken (bkz. Lim, 1996), diğerleri sosyal desteğin iş güvencesizliğinin etkilerine karşı etkili bir tampon oluşturmadığını göstermiştir (bkz. Hellgren \& Chirumbolo, 2003; Mak \& Mueller, 2000; Van den Tooren \& de Jong, 2014). Diğer çalışmalar iş güvencesizliği ile başa çıkabilmek için mevcut durumun değiştirilmesi, uzlaşma, değer düşürme ve semptomların azaltılması gibi doğrudan başa çıkma 
stratejileri kullanan çalışanların iş güvencesizliğinin olumsuz etkilerinden daha az etkilendiğini (Cheng vd., 2014b), kaçınma stratejisine başvuran çalışanların ise iş güvencesizliğinden daha fazla etkilendiği bulmuştur (Cheng vd., 2014b; Mantler vd., 2005).

Tüm bu bulgular bir arada düşünüldüğünde, bireysel özelliklerin çalışanların işlerinin devamlılığına dair algıladıkları tehdit karşısındaki tepkilerini şekillendirebileceği görülmektedir. Ancak bu konuya odaklanan çalışmaların sınırlı sayıda olması ve mevcut çalışmaların çelişkili bulgular doğurması, bu konuda ek çalışmalara ihtiyaç duyulduğunu göstermektedir. Gelecek araştırmaların bir taraftan yazındaki çelişkili bulguları anlamaya çalışması, diğer taraftan da henüz incelemeyen olası diğer bireysel faktörlerin (örn. beş faktör kişilik özellikleri, mizaç, duygu işleme hassasiyeti) düzenleyici rolünü irdelemesi önerilebilir.

\section{8. İş ve Örgüt ile İlgili Faktörlerin İş Güvencesizliğinin Etkilerini Düzenlemedeki Rolü}

Geçmiş araştırmacılar çalışanların bireysel özelliklerin ötesinde, iş ve örgüt ile ilgili bazı faktörlerin de iş güvencesizliğinin olumsuz etkilerini düzenleyebileceğini öne sürmüştür. $\mathrm{Bu}$ kapsamda, işe bağımlılık, işe katılım, iş kontrolü, algılanan istihdam edilebilirlik ve iş özerkliği üzerinde durulan değişkenler olmuştur.

\section{9. İşe Bağımlılık ve İşe Katılımın Düzenleyici Rolü}

Hobfoll'un (1989) kaynakların korunması kuramına göre, bireyin iyilik hali, sahip olunan kaynakların korunmasına ve devamlılığına bağlıdır. Kurama göre mevcut kaynaklar kaybedildiğinde ya da buna dair bir tehdit algılandiğında stres oluşur ve birey zarar görür. İş güvencesizliği durumunda, istikrarlı istihdam ve ona bağlı olan bazı değerli iş özellikleri tehdit altında algılandığ 1 için çalışanların iyilik halinin zarar görmesi beklenen bir durumdur (Hobfoll, 1989). Hatta bazı araştırmacılar (örn. Selenko \& Batinic, 2012) iş güvencesizliği ile iyilik hali arasındaki olumsuz ilişkinin tamamıyla kaynak kaybı tehdidi ile açıklanabileceğini ileri sürmüştür. Ancak bu noktada, iki önemli soru ortaya çıkmaktadır: Neden bazı çalışanlar iş güvencesizliğini bir kaynak kaybı tehdidi olarak algılarken, diğerleri algılamaz ve neden bazı çalışanlar iş güvencesizliğinden daha olumsuz etkilenir?

$\mathrm{Bu}$ sorulara odaklanan bazı araştırmacılar, işe bağımlılığın (birey için sağladığı kaynaklardan dolayı işe duyulan ihtiyaç, Richter, Naswall, Bernhard-Oettel \& Sverke, 2014) bu konudaki rolüne vurgu yaparak sadece işe ve işin sağladığı kaynaklara önem veren çalışanların iş güvencesizliğinden olumsuz etkileneceğini iddia etmektedir. İşe bağımlılık bakış açısına (bkz. Greenhalgh \& Rosenblatt, 1984, 2010) göre bireyler işlerini korumaya ve değerli iş özelliklerini sürdürmeye ne kadar çok önem verirse iş güvencesizliği algısından o kadar fazla olumsuz etkilenir (Ashford vd., 1989; Sverke vd., 2002). Richter vd. (2014) işe bağımlılığın iş güvencesizliği (nicel ve nitel) ve çalışan iyilik hali ilişkisindeki düzenleyici rolünü araştırarak bu varsayımı görgül olarak incelemiştir. Çalışmada işe bağımlılık, finansal işe bağımlılık (öznel finansal bağımlılık ve hane halkı gelirine göreceli katkı) ve psikolojik işe bağımlılık (işe katılım) olarak iki farklı şekilde tanımlanmıştır. Araştırmacılar, kaynakların korunması kuramı (Hobfoll, 1989) ve işe bağımlılık bakış açısına (Greenhalgh \& Rosenblatt, 1984, 2010) dayanarak çalışanların iş güvencesizliğinden ne düzeyde etkileneceğinin bu kişilerin işin sağladığı kaynakların korunmasına ne kadar önem verdiğine bağlı olarak değiştiğini öne sürmüştür. Bulgular, finansal ve psikolojik işe bağımlılığın nicel ve nitel iş güvencesizliği ile iş tatmini arasındaki ilişkiyi düzenlediğini göstermiştir. Ancak işe bağımlılığın düzenleyici etkisi beklenenin tersi yönde bulunmuştur: Öznel işe bağımlılığı ve işe katılımı daha yüksek olan çalışanlar ile hane haklı gelirinin ana sağlayıcısı olan çalışanların iş güvencesizliğinden daha az etkilendiği görülmüştür. Araştırmacılar bu beklenmedik bulguları işe bağımlılığın iş güvencesizliğinin olumsuz etkilerini mutlaka kötüleştirmeyeceğini, aksine çalışanların işlerine olan bağımlılıklarını iş güvencesizliği algısı ile başa çıkabilmek için bir yol olarak kullanabileceğini vurgulayarak açıklamıştır.

İşe katılımın iş güvencesizliğinin olumsuz etkileri ile başa çıkma konusundaki kritik rolü diğer araştırmalar tarafından da desteklenmiştir. Stiglbauer vd. (2012) iş güvencesizliği ve iyilik hali arasındaki olumsuz ilişkinin, yüksek iş katılımı bildiren çalışanlar arasında nispeten zayıf olduğunu göstermiştir. Daha sonraki bir çalışmada, Stiglbauer ve Batinic (2015) iş güvencesizliği ile başa çıkabilmek için kullanılan stratejilerin etkililiğinin çalışanların işe katılım seviyesine bağlı olarak değiştiğini öne sürerek iş katılımının iş güvencesizliği konusundaki kritik rolüne vurgu yapmıştır. $\mathrm{Bu}$ çalışmada araştırmacılar, proaktif başa çıkma stratejisi (potansiyel stresli olay meydana gelmeden önce önlem almak, Stiglbauer \& Batinic, 2015: 266) kullanmanın çalışanları iş güvencesizliğinin olumsuz etkilerinden koruyabileceğini, ancak bu durumunun sadece işe katılımı yüksek olan çalışanlar için geçerli olacağını 
öne sürmüştür. Bulgular araştırmacıların beklentilerini desteklemiş, proaktif başa çıkma stratejisi kullanmanın işe katılımı yüksek olan çalışanlar arasında olumsuz iş güvencesizliği ve iyilik hali ilișkisini hafiflettiğini; buna karşın işe katılımı düşük olan çalışanlar arasında bu ilişkiyi güçlendirdiğini ortaya çıkarmıştır.

Sonuç olarak, yukarıda bahsedilen araştırmaların bulguları, işin ve değerli iş özelliklerinin kaybedilmesine dair algılanan tehdidin çalışanlar açısından olumsuz sonuçlar doğurabileceğini göstermekte, ancak işe bağımlılık ve işe katılım gibi iş ile ilgili bazı faktörlerin çalışanları iş kaybı tehdidinin olumsuz etkilerinden koruyabileceğini ortaya koymaktadır.

\subsection{0. İş Kontrolü, İş Özerkliği ve Algılanan İstihdam Edilebilirlik Değişkenlerinin Düzenleyici Rolü.}

Batı yazınında iş kontrolü (job control), iş özerkliği (job autonomy) ve algilanan istihdam edilebilirlik (perceived employability) birer iş kaynağı olarak değerlendirilmiş ve bu kaynakların iş güvencesizliğinin etkilerini düzenleme rolleri iş talep-kontrol (Karasek, 1979) ve iş talep-kaynak (Demerouti, Bakker, Nachreiner \& Schaufeli, 2001; Bakker \& Demerouti, 2007) modelleri çerçevesinde incelenmiştir.

İş talep-kontrol modeli (Karasek, 1979) iş güvencesizliği ve çalışan iyilik hali ilişkisini açıklayan en etkili modellerden birisidir (Häusser, Mojzisch, Niesel \& Schulz-Hardt, 2010; Schreurs, Van Emmerik, Notelaers \& De Witte, 2010). Bu modelde iş talebi ve iş kontrolü olmak üzere çalışma ortamının iki boyutu üzerinde durulur. İş talebi, iş yükü ve zaman baskısı gibi, çalışma ortamında stres yaratan faktörler olarak, iş kontrolü ise çalışanların iş günü boyunca görevlerini ve davranışlarını kontrol edebilme potansiyeli olarak tanımlanır (Karasek, 1979). Temel olarak iş taleplerinin gerilimi ve stresi $\operatorname{arttırdığ~} 1$, iș kontrolünün ise iş taleplerinin çalışan üzerindeki olumsuz etkisini hafiflettiği savunulur.

$\mathrm{Bu}$ modeli temel alan bazı çalışmalar, iş güvencesizliğinin etkileri konusunda iş kontrolünün düzenleyici etkisine odaklanmıştır. Bulgular genel olarak iş talep-kontrol modelini desteklemiş, yüksek düzeyde iş kontrolüne sahip olduğunu düşünmenin iş güvencesizliğinin olumsuz etkisini hafiflettiğini göstermiştir (bkz. Schreurs vd., 2010). $\mathrm{Bu}$ bulgu boylamsal çalışmalar tarafindan da desteklenmiş, yüksek iş kontrolüne sahip olmanın iş güvencesizliğinin çalışan üzerindeki olumsuz etkilerini uzun vadede de hafiflettiği bulunmuştur (bkz. Cheng vd., 2014a). Buna karşın, algılanan işyeri kontrolünün ("işyyerindeki olumsuz olaylardan kendini koruyabilme becerisi”) düşük olduğu durumda, iş güvencesizliğinin sağlık problemleri ile olumlu yönde ilişkili olduğu gözlenmiştir (Barling \& Kelloway, 1996: 253).

Özetle, yukarıda sunulan bulgular iş kontrolünün çalışanların iş güvencesizliğinden nasıl ve ne oranda etkileneceğini göstermekte ve çalışanların algıladıkları iş kontrolünü yükseltmenin iş güvencesizliğinin olumsuz etkilerine karşı görece koruyucu olduğunu ortaya koymaktadır. Ancak bu noktada üzerinde düşünülmesi gereken bir konu iş kontrolünün bütün örgütsel stres-gerginlik ilişkisini açıklama konusunda tek başına yeterli olup olmadığıdır. İş talep-kontrol modelinin eleştirildiği nokta tam olarak burasıdır. Eleştiriler iş talepkontrol modeli tarafindan vurgulanan sinırlı sayıdaki değişkenin (iş kontrolü, iş yükü, zaman baskısı) örgütlerin karmaşık doğasını açıklama konusunda yetersiz kalacağını ileri sürmekte, çalışma hayatındaki stres-gerginlik ilişkisini daha iyi anlayabilmek için diğer iş kaynaklarının ve iş taleplerinin etkilerinin de göz önünde bulundurulması gerektiğini vurgulamaktadır (bkz. Bakker \& Demerouti, 2007)

İş talep-kaynak modeli (Demerouti vd., 2001; Bakker \& Demerouti, 2007), iş kontrolü dışında kalan iş kaynaklarının (örn. amir ya da iş arkadaşı desteği, rol netliği, performans geribildirimi) ve iş yükü ve zaman baskısı dışında kalan iş taleplerinin (örn. iş güvencesizliği, yüksek iş baskısı, kötü fiziksel çevre koşulları, duygusal talepler) örgütsel stres-gerginlik ilişkisindeki olası etkilerine odaklanarak iș talep-kontrol modelinin kapsamını genişletmiştir (Bakker \& Demerouti, 2007). Bu modelde iş talepleri, çalışanların sorunlu olarak değerlendirdiği ve dolayısıyla bazı fizyolojik ve/veya psikolojik sorunlarla ilişkili olduğu düşünülen iș boyutları olarak tanımlanır. İș kaynakları ise iş hedeflerini gerçekleştirmeyi kolaylaştıran, iş talepleri ile ilişkili maliyetleri düşüren, çalışanları kişisel büyüme, öğrenme ve geliştirme için motive eden iş boyutları olarak tanımlanmaktadır (Baker \& Demerouti, 2007). İş talep-kaynak modelinin temel varsayımı (iş kaynakkontrol modelinde olduğu gibi) mevcut iș kaynaklarının iş taleplerinin çalışan üzerindeki etkisini azalttığıdır.

İş güvencesizliği durumunda, iş özerkliği ve algılanan istihdam edilebilirlik, iş güvencesizliğinin olumsuz etkilerini hafifletebilecek kritik iş kaynakları olarak düşünülmüştür. Van den Tooren ve de Jong (2014) iş özerkliğinin iş güvencesizliğinin iş tatmini üzerindeki olumsuz etkisini yatıştırdığını bularak iş özerkliğinin iş güvencesizliği karşısındaki tampon rolünü 
desteklemiştir. Ancak araştırmalar algılanan istihdam edilebilirliğin (bireyin yeni bir iş bulabilme olanağına ilişkin algısı, Berntson \& Marklund, 2007: 281) düzenleyici rolü ile ilgili bazı çelişkili bulgular doğurmuştur. Silla, De Cuyper, Gracia, Peiro ve De Witte (2009) algılanan istihdam edilebilirliğin iş güvencesizliğinin yaşam doyumu üzerindeki olumsuz etkisini hafiflettiğini bulmuştur. Ancak Fatimah, Noraishah, Nasir ve Khairuddin (2012) algılanan istihdam edilebilirlik ile yakından ilişkili olan istihdam güvenliğinin (employment security), iş güvencesizliği ve iyilik hali arasındaki ilişkisinde anlamlı bir düzenleyici değişken olduğunu gösterememiştir.

Toparlamak gerekirse, yukarıda sunulan araştırma bulguları, iş talep-kontrol ve iş talep-kaynak modellerinin iş güvencesizliğinin çalışan üzerindeki olumsuz etkilerini açıklamak için kullanılabileceğini göstermekte ve bazı iş kaynaklarının (iş kontrolü, iş özerkliği ve algılanan istihdam edilebilirlik) iş güvencesizliğinin etkilerini şekillendirebileceğine kanıt sunmaktadır. $\mathrm{Bu}$ bulgular algılanan iş güvencesizliğin yol açtığ etkileri ve bu etki düzeyinde gözlenen bireysel farklılıkları anlama konusunda değerli bilgiler sunmaktadır.

\subsection{Kültürel Değerlerin İş Güvencesizliğinin Etkilerini Düzenlemedeki Rolü}

İş güvencesizliğinin çalışanın iyilik hali üzerindeki etkisini inceleyen bazı araştırmalar bu etkinin daha iyi anlaşılabilmesi için kültürel farklılıklara ve kültürel değerlerinin etkisine odaklanmak gerektiğini vurgulamıştır. $\mathrm{Bu}$ anlamda araştırmacıların üzerinde durduğu kültürel değerler toplulukçuluk ve gelenekçiliktir.

Probst ve Lawler (2006), bireycilere oranla, toplulukçu kültürlerde çalışanların iyi çalışma koşullarına sahip olmaya ve güvenceli bir işte çalışmaya daha fazla önem verdiğini (Hofstede, 1980; Gomez, 2003; Oyserman, Coon \& Kemmelmeiser, 2000; Shwartz \& Bardi, 2001) dikkate alarak iş güvencesizliğinden daha olumsuz etkileneceğini öne sürmüştür. Bireysel ve ulusal düzeyde yapılan analizlerin sonuçları araştırmacıların bu beklentilerini doğrulamış, nispeten toplulukçu olan kişi ve ülkelerin (örn. Çin) bireyci olan kişi ve ülkelere (örn. ABD) oranla iş güvencesizliğinden daha olumsuz etkilendiğini göstermiştir. Bir diğer kültürel değer olan gelenekçiliğin etkisini inceleyen Wang, Lu \& Lu (2014) ise gelenekçiliğin belirsiz iş ortamına karşı bireylerin duyarlılığını arttırabileceğini dikkate alarak geleneksel değerlere daha fazla önem veren çalışanların iş güvencesizliğine daha olumsuz tepki vereceğini öne sürmüştür. Bulgular daha gelenekçi olan çalışanların iş güvencesizliği durumunda daha fazla sağlık problemi yaşadığını göstererek araştırmacıların beklentisini desteklemiştir. $\mathrm{Bu}$ iki araştırma bir arada düşünüldüğünde, toplulukçuluk ve gelenekçiliğin iş güvencesizliği algısının çalışanlar üzerindeki olumsuz etkisini artırdığ söylenebilir. Ayrıca araştırılan kültürel değerlerin düzenleyici rollerine ilişkin anlamlı bulgular farklı kültürel değerlerin de (örn. güç mesafesi, belirsizlikten kaçınma, kısa/uzun vadeli yönelim) iş güvencesizliğine verilen tepkileri etkileyebileceğinin sinyalini vermektedir.

Sonuç olarak, yukarıda bahsedilen çalışma doğurguları, farklı bireylerin iş güvencesizliğinden farklı şekillerde etkilendiğini göstermektedir. Mevcut derleme çalışması bu farklılığa etki eden faktörlerden bazılarının yaş, görev süresi, cinsiyet ve mesleki statü gibi demografik faktörler; kişilik, düzenleme odağı ve kullanılan başa çıkma stratejileri gibi bireysel özellikler; iş bağımlılığı, işe katılım, iş kontrolü, iş özerkliği, algılanan istihdam edilebilirlik gibi iş ve örgüt ile ilgili bazı faktörler ile toplulukçuluk ve gelenekçilik gibi kültürel faktörler olduğunu ortaya koymaktadır.

\section{YÖNTEM}

\subsection{Yazın Araştırması ve Dahil Edilme Kriterleri}

$\mathrm{Bu}$ derleme çalışmasında, iş güvencesizliği ile ilgili öncü makalelere ek olarak, iş güvencesizliği ve iyilik hali ilişkisindeki düzenleyici faktörleri araştıran çalışmalar bir araya getirilmiştir. Makale taraması Scopus veri tabanı (www.scopus.com) kullanılarak yapılmıştır. Taramada kullanılan anahtar kelimeler, Türkçe ve İngilizce olarak, iş güvensizliği (job insecurity), iş güvencesi (job security), iyilik hali (well-being), başa çıkma (coping with), tamponlama (buffering) ve düzenleyici değişkendir (moderator). Makale taraması, Türkçe, İngilizce dilleri ve psikoloji alanı ile sınırlandırılmış, diğer taraftan makale yılı sınırlandırması yapılmamıştır. $\mathrm{Bu}$ dahil edilme ölçütleri sonucunda bulunan makaleler incelenmiş, iş güvencesizliğini bağımsız değişken ve iyilik halini bağımlı değişken olarak alan çalışmalar mevcut derleme kapsamına alınmıştır. İyilik hali bağımlı değişkeni taramasında karşılaşılan, yaşam doyumu, iş doyumu, fiziksel ve psikolojik sağlik değişkenlerini bağımlı değişken olarak alan makaleler de bu derlemeye dahil edilmiştir. Sonuç olarak, bahsedilen ölçütlere uygun olarak saptanan ve bu derleme kapsamında değerlendirilen 23 çalışma Tablo1'de örneklem özellikleri, ele alınan bağımlı değişkenler, düzenleyici değişkenler ve temel bulguları dikkate alınarak özetlenmiştir. 
Tablo 1: Derleme Çalışmasında Yer Alan Makalelerin Temel Özellikleri ve Bulguları

\begin{tabular}{|c|c|c|c|c|}
\hline Makale & Örneklem & Bağımlı Değişken(ler) & Düzenleyici(ler) & Önemli Bulgu(lar) \\
\hline $\begin{array}{l}\text { Barling ve Kelloway } \\
\text { (1996) }\end{array}$ & $\begin{array}{l}187 \text { Güney Afrikalı } \\
\text { altun madencisi. }\end{array}$ & $\begin{array}{l}\text { Psikosomatik semptomlar, } \\
\text { Olumsuz ruh hali (negative mood), } \\
\text { Kan basinc1. }\end{array}$ & İ̧syeri kontrolü. & $\begin{array}{l}\text { İ ģ̈vencesizliği, düşük olarak algılanan işyeri kontrolü } \\
\text { durumunda, psikosomatik belirti ve kan basıncs ile olumlu } \\
\text { yönde ilişkiliyken, yüksek işyeri kontrolü durumunda, bu } \\
\text { değişkenler ile ilişkili bulunamamıştr. }\end{array}$ \\
\hline $\begin{array}{l}\text { Cheng ve Chan } \\
\text { (2008) }\end{array}$ & $\begin{array}{l}133 \text { çalıımanin } \\
\text { sonuçlarııın } \\
\text { derlendiği meta- } \\
\text { analiz çalış̧ması. }\end{array}$ & $\begin{array}{l}\text { İs ile ilgili sonuçlar, } \\
\text { Sağlik ile ilgili sonuçlar. }\end{array}$ & $\begin{array}{l}\text { Demografik faktörler: } \\
\text { Görev süresi, } \\
\text { Yaş, } \\
\text { Cinsiyet. }\end{array}$ & $\begin{array}{l}\text { Yaş ve görev süresi, iş güvencesizliği - çalışan sağliğı } \\
\text { ilişkisini düzenlemektedir. Olumsuz iş - çalışan sağlığı } \\
\text { ilişkisi, daha yaşlı olan (gençlere kiyasla) ve daha uzun } \\
\text { zamandır çalışanlar (kısa zamandır çalışanlara kıyasla) } \\
\text { arasında daha güçlüdür. }\end{array}$ \\
\hline Cheng vd. (2014a) & $\begin{array}{l}\text { *Üç-dalga boylamsal } \\
\text { veri. }\end{array}$ & $\begin{array}{l}\text { İs başında canllikk (vigor at work), } \\
\text { İs tatmini, } \\
\text { Iş-aile zenginleștirmesi (work- } \\
\text { family enrichment). }\end{array}$ & $\begin{array}{l}\text { Başa çikma kaynakları: } \\
\text { İs kontrolü, } \\
\text { Sosyal destek, } \\
\text { İimserlik. }\end{array}$ & 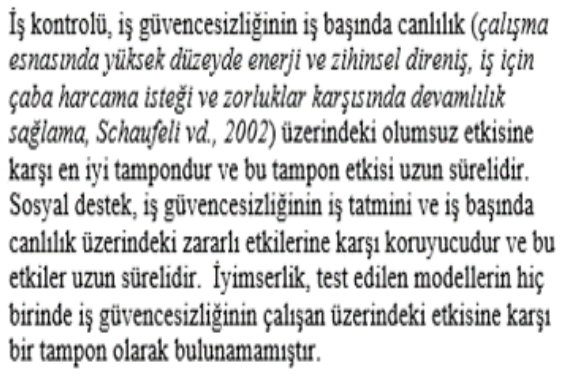 \\
\hline
\end{tabular}

Cheng vd. (2014b) 2764 Finlandiyals çalışan.
Kişisel başa çıkma stratejileri:

Mevcut durumun değiştirilmesi, Uzlaşma (accommodation)

Belirtilerin azaltulmast (symptom reduction)

Değer đüşürme, Kaçinma.
Doğrudan (engaged) başa çıkma stratejilerinden (durumu değiştirme, uzlaş̧ma, belirti azaltma ve değer düşürme) yararlanmak is gūvencesizliğinin iyilik hali üzerindeki olumsuz etkilerini hafifletmiştir. Tersine, kaçnmma stratejisinin sık kullanımı, olumsuz iṣ güvencesizliği - ivilik hali iliş̧isini güclendirmiştir. home).

\begin{tabular}{|c|c|c|c|}
\hline Dekker ve Schaufeli & Avustralya'da & Psikolojik sağlik. & Başa çikma kaynaklan \\
\hline & $\begin{array}{l}\text { būyük bir toplu } \\
\text { taşıma firmasında } \\
\text { çalışan } 95 \text { kişi. }\end{array}$ & & $\begin{array}{l}\text { İ arkadaşı, yönetim vo } \\
\text { sendika desteği. }\end{array}$ \\
\hline & "Boylamsal çalışma. & & \\
\hline De Witte (1999) & $\begin{array}{l}\text { Belçika'da metal } \\
\text { isleme endüstrisinde }\end{array}$ & tyi oluş. & Demografik faktōrler \\
\hline & çalışan 336 kişi. & & Mesleki pozisyon, \\
\hline & & & Cinsiyet, \\
\hline & & & Yaş. \\
\hline
\end{tabular}

Sosyal destek (iş arkadą̧ı, yõnetim ve sendika desteği), is güvencesizliğinin çalı̨̧̨an üzerindeki olumsuz etkisini ortadan kaldırmamaktadir. Araşturmacilar, sosyal desteğin stres tamponlayıc bir etkisinin olmayabileceğini ileri sürmüştür.
Cinsiyet, iş güvencesizliği - iyilik hali ilişkisini düzenler: Is güvencesizliğinin kadılarda psikolojik iyilik hali ile ilişkili olduğu bulunmazken, erkeklerde artan sikint (distress) ile iliģkili olduğu gösterilmiştir. Mesleki pozisyon ve yas, iş güvencesizligig - iylik hali iliskisinde anlamlı birer düzenleyici faktờr olarak bulunamamıştrr. 
Tablo I: Derleme Çalışmasında Yer Alan Makalelerin Temel Özellikleri ve Bulguları (Devamı)

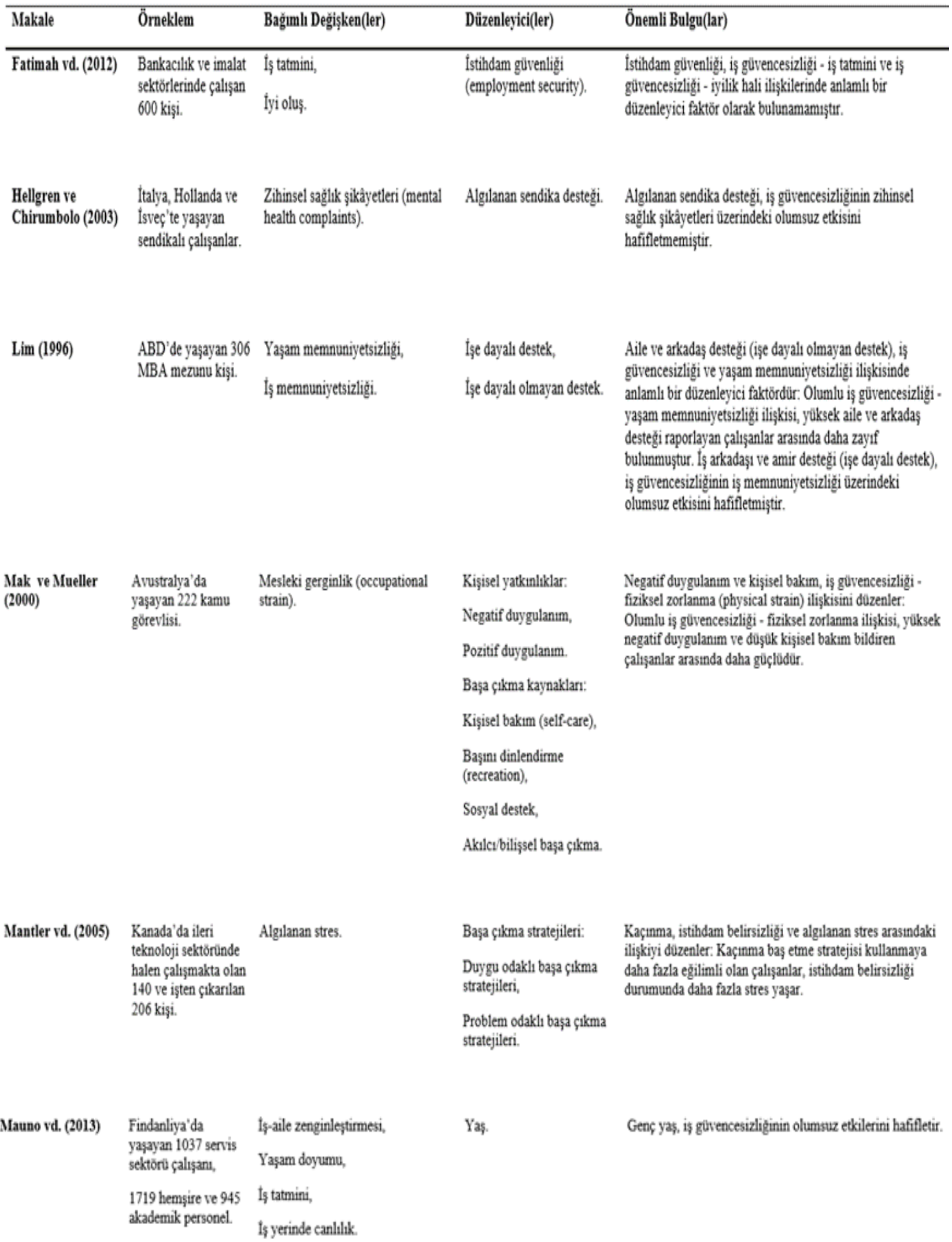


Tablo 1: Derleme Çalışmassnda Yer Alan Makalelerin Temel Ozellikleri ve Bulgulan (Devamı)

\begin{tabular}{lllll}
\hline Makale & Orneklem & Bağmlı Değjskken(ler) & Düzenlegici(ler) & Onemli Bulgu(lar) \\
\hline
\end{tabular}

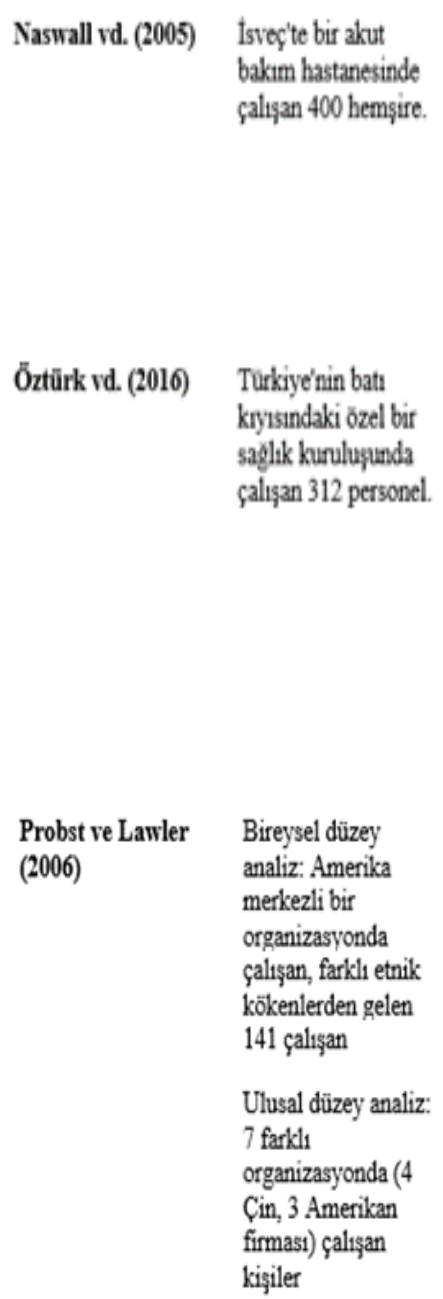

Zihinsel sag̣luk şikàyetleri,

$\$$ memnuniyetsizligi,

Is kaynakl gerginlik (job-induced tention).

Duygusal tukenmişlik.

Iş tatmini,

İs stresi,

Is güvencesizligine karşı verilen duygusal tepkiler.

Richter vd. (2014) Isveç'te bir muhasebe Iş tatmini, sirketinde calisan 553 kişi.

Zihinsel sağlik.

Finansal işe bağımlalik:

Öznel finansal bağımlilik,

Hane halka gelirine göreceli katk,

Psikolojik işe bağımlilik:

Işe katilim.

Is kontrolü,

Iş öz-yeterliliği (job selfefficacy).
Dı̨̧ kontrol odağı, is gutvencesizligi - zihinsel sağlik șikâyetleri iliģkisini düzenler: Yuksek iş guvencesizliğ durumunda, yüksek dıģ kontrol odağgna sahip çalıģanlar, duģuk deş kontrol odağgna sahip olanlara kiyasla daha fazla zihinsel sağlak șikşyeti bildirmisţir. Ancak důşuk iş gövencesizliğ dunumunda, is güvencesizligg - zihinsel sağltk şikâyetleri lisigkisi, dış kontrol odağının bir fonksiyonu olarak degismemiştir.

Is güvencesizliģi ve duygusal tukenmiglik arasında, yalnuzca yuksek kronik konunma odaģina sahip çlişanlar arasunda anlaml bir iligki bulunmugtur. Duygusal örgutsel bağllik, is guvencesizligi ve duygusal tukenmiglik arasndaki iliqkide anlamlı bir duzzenleyici faktốr deģildir. Anlamlı bir 3 younlu etkileşim etkisi goozlemlenmigtir: Duygusa orguitsel bagllalk, yuksck kronik konunma odaklı çalıganlar arasundaki pozitif is gövencesizligi - duygusal tukenmişlik iliskisini ortadan kaldrmıs, doquk korunma odakli çalıganlar arasinda ise bu ilişkiyi güçlendirmiştir.

Bireysel düzey analiz: Düşük düzey is güvencesizliği durumunda, toplulukçular örgütsel dönüsüm duyurusuna (announcement of organizational transition) bireyselcilere kyyasla daha olumsuz tepki vermiştir.

Ulusal düzey analiz: İ gürencesizliği durumunda, Çinli çalışanlar Amerikalilara göre daha düşük iş tatmini raporlamişlardir.

$\begin{array}{llll}\text { Schreurs vd. (2010) } & \begin{array}{l}\text { 1368 Belçikalı } \\ \text { çalı̧̧an. }\end{array} & \begin{array}{l}\text { lyileşme ihtiyacı (need for } \\ \text { recovery), }\end{array} & \text { İ̧ kontrolü, } \\ & \text { Zarar görmüş genel sağltk. } & \begin{array}{l}\text { İ̧ öz-yeterliliģi (job self- } \\ \text { efficacy). }\end{array}\end{array}$

Öznel finansal bağımllikk, hane halla gelirine katka ve işe katilim, nitel ve nicel is güvencesizliği ile is doyumu arasndaki olumsuz iligkiyi hafifletmistir. Yüksek düzeyde öznel finansal bağımlilik belirten, hane halks gelirine ana katka sağlayan ve yüksek düzeyde iş merkezliliği (work centrality) raporlayan çalışanlar, is güvencesizliğinin olumsuz etkilerinden daha az etkilenmistir.

İ̧ kontrolü, is güvencesizliğinin çalıģan sağliğı üzerindeki olumsuz etkilerini dindirir. 
Tablo 1: Derleme Çahısmassnda Yer Alan Makalelerin Temel Ozellikleri ve Bulgulan (Devama)

\begin{tabular}{|c|c|c|c|c|}
\hline Makale & Orneklem & Baģımh Deģiskea(ler) & Dũzealeyici(ler) & Onemli Bulgu(br) \\
\hline Silla vd. (2009) & 639 Belçikalı çalışan. & $\begin{array}{l}\text { Psikolojik sikunt (psychological } \\
\text { distress) } \\
\text { Yaşam doyumu. }\end{array}$ & $\begin{array}{l}\text { Algilanan istihdam } \\
\text { edilebilirlik. }\end{array}$ & 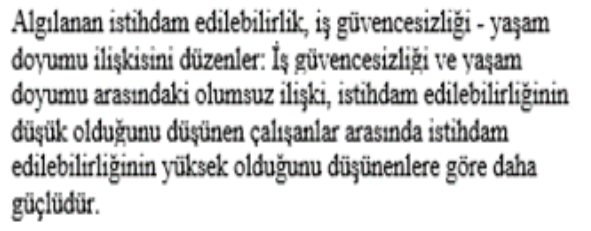 \\
\hline $\begin{array}{l}\text { Stiglbauer ve } \\
\text { Batinic (2015) }\end{array}$ & $\begin{array}{l}162 \text { Avusturyalı } \\
\text { ve } 444 \text { Tayvanlı } \\
\text { çalışan. }\end{array}$ & Mutluluk, Depresyon. & $\begin{array}{l}\text { Proaktif başa çilkma, } \\
\text { İse katulim (work } \\
\text { involvement). }\end{array}$ & 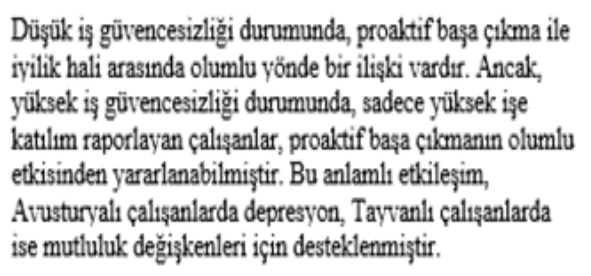 \\
\hline $\begin{array}{l}\text { Stiglbauer vd. } \\
\text { (2012) }\end{array}$ & $\begin{array}{l}178 \text { online panel } \\
\text { üyesi. } \\
\text { "İki-dalga boylamsal } \\
\text { veri. }\end{array}$ & $\begin{array}{l}\text { Duygusal iyilik hali, } \\
\text { Bilişsel iyilik hali. }\end{array}$ & $\begin{array}{l}\text { Işe katulim (work } \\
\text { involvement). }\end{array}$ & 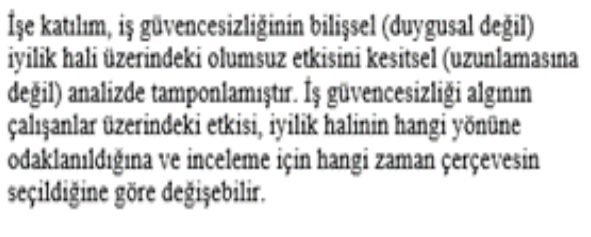 \\
\hline Sverke vd. (2002) & $\begin{array}{l}72 \text { çalışmanin } \\
\text { sonuçlarııin } \\
\text { derlendiği meta- } \\
\text { analiz çalışması. }\end{array}$ & $\begin{array}{l}\text { Iş tutumları, } \\
\text { Örgütsel Tutumlar, } \\
\text { Sağlik, } \\
\text { Iş ile ilgili davranışlar. }\end{array}$ & $\begin{array}{l}\text { İ̧ güvencesizliği } \\
\text { ölçümünün türü (madde ve } \\
\text { olçek), } \\
\text { Mesleki durum (manuel ve } \\
\text { manuel olmayan çalı̧̧an) }\end{array}$ & 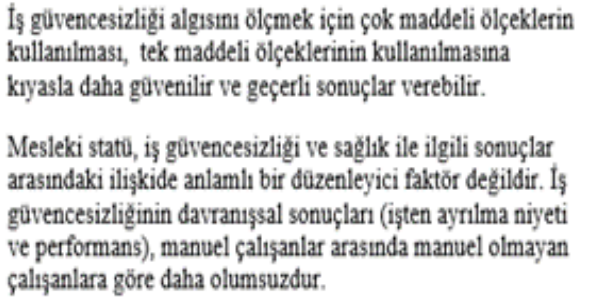 \\
\hline $\begin{array}{l}\text { Van den Tooren ve } \\
\text { de Jong (2014) }\end{array}$ & $\begin{array}{l}\text { Farkh ülke, sektồr ve } \\
\text { işlerde çalı̧̧an } \\
3845 \text { çalıģan. }\end{array}$ & $\begin{array}{l}\text { Iş tatmini, } \\
\text { Genel sağlik. }\end{array}$ & $\begin{array}{l}\text { Özerklik (autonomy), } \\
\text { Sosyal Destek, } \\
\text { Sözleşme tipi } \\
\text { (geçici veya sürekli } \\
\text { sỏzleşme). }\end{array}$ & 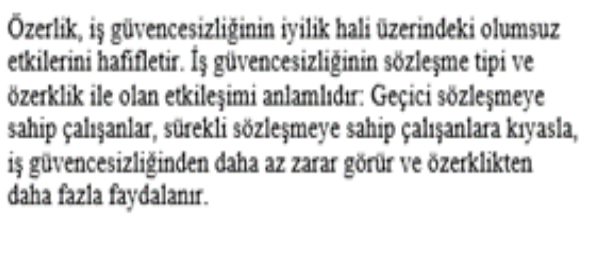 \\
\hline Wang vd. (2014) & $\begin{array}{l}\text { Cin'de çalışan } 388 \\
\text { kişi. }\end{array}$ & Iyi oluş. & Gelenekçilik. & $\begin{array}{l}\text { Geleneksel değerlere daha fazla önem veren çalışanlar, iş } \\
\text { güvencesizliğg durumunda daha fazla sağlık problemi } \\
\text { bildirir. }\end{array}$ \\
\hline
\end{tabular}

Not. Tabloda sunulan makaleler alfabetik sıraya göre düzenlenmiştir. Derlemeye dahil edilen çalışmalarının tümünün bağımsız değişkeni iş güvencesizliğidir. 
Mevcut derleme kapsamına giren çalışmalara ait bilgilerinin yer aldığı Tablo 1 incelendiğinde, yaş, görev süresi, cinsiyet, mesleki statü, kişilik, düzenleme odağı, kullanılan başa çıkma stratejileri, işe bağımlılık, ișe katılım, iş kontrolü, algılanan istihdam edilebilirlik, iș özerkliği, toplulukçuluk ve gelenekçilik değişkenlerinin iş güvencesizliğinin çalışan iyilik hali üzerindeki etkilerini düzenlendiği görülmektedir.

\section{TARTIŞMA VE SONUÇ}

Çalışma yaşamında olup bitenler hayatın diğer alanlarını doğrudan ya da dolaylı olarak etkiler. Çalışma hayatında karşılaşılan sorunların başında işin garantide olmadığına ilişkin algılanan tehdit gelmektedir ve bu algı çalışanın genel iyilik halini olumsuz şekilde etkileyebilmektedir. İşin devamlılığının sona ermesi (iş kaybı) ya da buna dair algılanan tehdidin (iş güvencesizliği algısı) birey üzerindeki olumsuz etkileri çok sayıdaki araştırmada gösterilmiştir (bkz. işsizliğin etkileri için, McKee-Ryan, Song, Wanberg \& Kinicki, 2005; Paul \& Moser, 2009; Wanberg, 2012; iş güvencesizliği algısının etkileri için, Cheng \& Chan, 2008; De Witte, 2005, Sverke vd., 2002). Psikoloji yazınında işsizlik ve etkilerinin kapsamlı olarak araştırılmasına karşın, iş güvencesizliği ve etkileri yeterince incelenmemiștir (Sümer vd., 2013). Aslında işsiz kalmanın ani ve bazen beklenmedik doğasından farklı olarak, sürekli olarak algılanan bugün-yarın işsiz kalınabileceği endişesi çalışanların iş yaşamını ve aslında tüm hayatını işsizlik kadar hatta belki de ondan daha fazla olumsuz etkileyebilmektedir. Bu derleme çalışması temel olarak iş güvencesizliği olgusunun çalışanların iyilik hali üzerindeki etkisine odaklanmış ve iş güvencesizliğine verilen farklı bireysel tepkilere iliş̧in bulguları temel alarak iş güvencesizliğinin çalışan üzerindeki etkilerini düzenleyen faktörler üzerinde durmuştur.

Yapılan yazın derlemesi, yaş, görev süresi, cinsiyet ve mesleki statü gibi demografik özelliklerin; kişilik, düzenleme odağı ve kullanılan başa çıkma stratejileri gibi bireysel etmenlerin; işe bağımlılık, işe katılım, iş kontrolü, algılanan istihdam edilebilirlik ve iş özerkliği gibi iş ve örgüt ile ilgili faktörlerin; ve toplulukçuluk, gelenekçilik gibi kültürel etmenlerin iş güvencesizliği ile iyilik hali arasındaki ilişkiyi düzenleyebileceğini göstermiştir. Genel olarak genç yaş, yüksek düzey işe bağımlılık, işe katılım, iş kontrolü, iş özerkliği ve stres ile başa çıkabilmek için problem odaklı, doğrudan başa çıkma stratejileri kullanmanın iş güvencesizliğinin olumsuz etkilerini hafiflettiğini görülmektedir. Buna karşın, görece ileri yaş, uzun süredir çalışma, yüksek düzey dış kontrol odağı, olumsuz duygulanım, toplulukçuluk ve gelenekçilik, düşük düzey kişisel bakım ve korunma odaklılığın ise bu olumsuz etkiyi güçlendirmiştir. Ancak özellikle cinsiyet, sosyal destek ve algilanan istihdam edilebilirliğin iş güvencesizliği ile iyilik hali ilişkisindeki düzenleyici rolüne dair çelişkili bulgular bu faktörlerin söz konusu ilişkideki etkisini tam manasıyla anlayabilmek için ek araştırmalara ihtiyaç duyulduğunu ortaya çıkarmıştır.

Var olanı göstermek, eksiğin ne olduğunu anlamanın en kolay yollarından birisidir. Mevcut çalışma, yazındaki bulguları bir arada sunarak iş güvencesizliği algısının kimler üzerinde ve hangi durumlarda daha fazla ya da daha az etkili olabileceğine işaret etmekte, böylelikle aslında üzerinde henüz araştırılmamış değişkenlere ${ }_{1 s ̧ ı k}$ tutmaktadır. Örneğin çalışanların olumlu olumsuz duygulanım dışındaki kişilik özellikleri (özellikle beş temel kişilik faktörü), bireysel dayanıklılık düzeyi, bağlanma yönelimi (güvenli ya da kaygılı veya kaçınan güvensiz bağlanmaya sahip olması), duygusal istikrar, başarı motivasyonu, dini inanç ve kadercilik, alkol tüketimi, iş merkeziyeti, örgütteki liderlik türü, örgüt iklimi ve ülkenin genel ekonomik durumu, bireyselcilik ve toplulukçuluk dışındaki kültürel özellikler (özellikle belirsizlikten kaçınma düzeyi, güç mesafesi, erkeksilik ve uzun dönem yönelim) çalışanların iş güvencesine verdiği tepkileri şekillendirebilir. İleride yapılacak çalışmalar bu değişkenlerin iş güvencesizliğinin etkilerini düzenleme konusundaki olası rolünü kuramsal olarak tartışabilir ve araştırabilir.

$\mathrm{Bu}$ derlemede görüldüğü gibi, iş güvencesizliğinin etkilerini inceleyen araştırmalar genel olarak stres kuramı (Lazarus \& Folkman, 1984), işe bağımlı olma perspektifi (Greenhalgh \& Rosenblatt, 1984), iş talep-kontrol (Karasek, 1979, 1998) ve iş talepkaynak (Demerouti vd., 2001; Bakker \& Demerouti, 2007) modelleri ile kaynakların korunması kuramından (Hobfoll, 1989) yararlanmıştır. Faydalanılan kuramsal yaklaşımlar iş güvencesizliğinin çalışanlar üzerindeki olumsuz etkilerini anlamaya yardımcı olmakla birlikte, iș güvencesizliğinin etkilerini tam manasıyla anlayabilmek için daha kapsamlı bir "şemsiye model" in gerekliliğine işaret etmektedir. Böylesi bir modelde, algılanan iş güvencesizliğini etkileyen (1) kültürel özellikler, sosyo ekonomik koşullar, dönemsel ve küresel krizler gibi görece uzak bağlamsal faktörler,

(2) iş ve örgüt ile ilgili faktörler, sosyal destek düzeyi, aile, diğer yakın ilişkiler gibi yakın bağlamsal faktörler ile kişilerarası süreçler ve

(3) kişilik özellikleri ve dayanıklılık gibi birey içi faktörler bir arada ele alınarak hem etkinin süreci hem de sonuç değişken olan algılanan iş güvencesizliğine yakınlığı sistematik olarak belirtebilir. 
$\mathrm{Bu}$ derleme çalışmasının son yıllarda yapılan ilgili temel araştırmaları derlemesine karşın düşünülen bazı kısıtlılıkları vardır. İlk olarak derleme için makale taraması, uluslararası düzeyde akademik makaleleri içeren en büyük veri tabanlarından birisi olan Scopus veri tabanı kullanılarak yapılmıştır. Ancak, Scopus dişındaki, Academic Search Complete, Business Source Complete, EBSCHO, Emerald, ERIC, DOAJ, IEEE XploreDigital Library, JTOR, PsycINFO, SageJournals Online, Science Direct, Web of Knowledge ve Web of Science gibi veri tabanlarının da taranması konuyla ilgili ek makalelere ulaşmayı sağlayabilir, böylelikle çalışma örnekleminin evreni temsil kabiliyetini kuvvetlendirebilir. Dolayısıyla ileride yapılacak çalışmalar taranacak veri tabanı kümesini daha geniş tutabilir.

Düşünülen diğer bir kısıt ise makale taraması yapılırken öznel (algılanan)/nesnel (objektif), bilişsel/duygusal, nitel/nicel iş güvencesizliğ ayrımlarının yapılmamış olmasıdır. Mevcut çalışmada iş güvencesizliği genel bir olgu olarak kabul edilmiştir. Oysa bu makalenin konusu olan düzenleyici değişkenler iş güvencesizliğinin tanımlanma şekline göre farklılık gösterebilir. Örneğin işini kaybetme kaygısı (nicel iş güvencesizliği) ile gelir, kariyer firsatları ve sosyal çevre gibi değer yüklenilen bazı iş özelliklerinin değişmesi endişesi (nitel iş güvencesizliği) çalışanlar açısından farklı sonuçlar doğurabilir. Ancak ilgili yazında her bir tanımlamaya karşılık gelecek yeterli sayıda çalışma bulunmadığından bu derlemede iş güvencesizliğinin tanımındaki ayrımlar dikkate alınmamıştır. Gelecek çalışmalarda özellikle nesnel ve öznel iş güvencesizliği ayrımı dikkate alınarak bulguların yorumlanması yararlı olacaktır.

Olası diğer bir kısıt ise yaşam doyumu, iş doyumu, fiziksel ve psikolojik sağlık değişkenlerinin iyilik halinin göstergeleri olarak kabul edilmesidir. Gelecek çalışmalarda her bir değişken için etkinin ayrı ayrı değerlendirilmesi yararlı olabilir. İyilik hali, hem yaşam kalitesi ve iş doyumu gibi bilişsel değerlendirmeleri hem de olumlu duygulanım ve mutluluk gibi duygusal değerlendirmeleri bir arada içerdiğinden (Diener, 1984) iş güvencesizliğinin iyilik halinin hangi yönünü daha fazla etkilediği de böylelikle daha iyi anlaşılabilir. Ayrıca tüm bu değişkenlerin ayrı ayrı bağımlı değişken olarak değerlendirilmesi iş güvencesizliğinin etkilerini düzenleyen değişkenler ile ilgili farklı bilgiler verebilir. Ancak bu ayrımları göz önünde bulunduran kapsamlı bir derlemenin yapılabilmesi için ilgili yazının belli bir doygunluğa erişmesinin beklenmesi gerekmektedir.
Gelecek çalışmalar için bir öneri de mevcut derleme kapsamında ele alınan ilişkilerin meta-analiz yöntemiyle incelenmesi ve etki genişliklerinin istatistiksel olarak gösterilmesidir. $\mathrm{Bu}$ konuda yapılan meta-analiz çalışması söz konusu değişkenler arasındaki ilişki hakkında daha genellenebilir ve güvenilir sonuçlara ulaşmayı sağlayabilir.

İlaveten, Shoss'un (2017) iş güvencesizliği konusunda yaptığı güncel yazın derlemesinde önerdiği gibi, iş güvencesizliği algısı ile bu algının çalışan ve örgütler üzerindeki etkisini daha iyi anlayabilmek için boylamsal çalışmalara ihtiyaç duyulmaktadır. Yine aynı derlemede ifade edildiği gibi araştırmacıların bireyin algıladığ 1 iş güvencesizliğinin etkilerinin ötesinde iş güvencesizliği ikliminin (iş güvencesizliği konusundaki paylaşılan algılar) olası sonuçları üzerinde düşünmesi ilgili yazına katkı sağlayacaktır.

Son olarak, yapılan çalışmalarda algılanan iş güvencesizliğine karşı birey, örgüt ve kamusal destek düzeyinde ne tür önlemler alınabileceği ve işini kaybetme korkusu yaşayanlara nasıl destek olunabileceği konusunda öneriler geliştirilmelidir. Sümer vd. (2013) yaptıkları kapsamlı araştırmanın sonucunda siyasi karar vericilerin, işverenlerin ve sendikaların bu konuda görevler üstelemesini, iş güvencesizliği algısını dikkate alan somut farkındalık programları ve müdahale yöntemleri geliştirmelerini önermektedir. Küresel olarak güvencesiz çalışmayı yaygınlaştıran yeni iş ve istihdam düzenlemeleri ve iş gücü piyasasındaki değişimler (Benach vd., 2014) dikkate alınarak bu konuda belirgin bir farkındalık geliştirilmesi ve kamusal önlemler alınması zorunlu görünmektedir.

Sonuç olarak, tüm katkı ve kısıtları bir arada düşünüldüğünde, bu çalışma farklı bireylerin iş güvencesizliğinden farklı şekillerde etkilenebileceğini ve bu algıya farklı tepkiler verebileceğini göstermesi; çalışanların demografik özelliklerinin (yaş, görev süresi, cinsiyet ve mesleki statü), bireysel faktörlerin (kişilik, düzenleme odağ 1 ve kullanılan başa çıkma stratejileri), iş ve örgüt ile ilgili etmenlerin (işe bağımlılık, işe katılım, iş kontrolü, iş özerkliği, algılanan istihdam edilebilirlik) ve kültürel faktörlerin (toplulukçuluk ve gelenekçilik) bu olguya verilen tepkilerdeki farklılığı oluşturabileceğini ortaya koyması; ilgili konuda kuramsal çerçeve olarak kullanılan yaklaşım, model ve perspektiflerin bir arada sunulması ve tüm bu bağlamları içeren bir şemsiye modelin oluşturmasının gerekliliğini göstermesi bakımlarından Türkçe yazına katkı sağlamış ve gelecek çalışmalar için bir bilgi kaynağı olmuştur. 


\section{KAYNAKÇA}

Allen, N. J. \& Meyer, J. P. (1990). The measurement and antecedents of affective, continuance and normative commitment to the organization. Journal of Occupational Psychology, 63, 1-18.

Ashford, S. J., Lee, C. \& Bobko, P. (1989). Content, causes and consequences of job insecurity: A theorybased measure and substantive test. Academy of Management Journal, 4(4), 803-829.

Bakker, A. B. \& Demerouti, E. (2007). The job demandsresources model: State of the art. Journal of Managerial Psychology, 22, 309-328.

Barling, J. \& Kelloway, E. K. (1996). Job insecurity and health: The moderating role of workplace control. Stress Medicine, 12, 253-259.

Benach, J., Vives, A., Amable, M., Vanroelen, C., Tarafa, G. \& Muntaner, C. (2014). Precarious employment: Understanding an emerging social determinant of health. Annual Review of Public Health, 35, 229-253.

Berntson, E. \& Marklund, S. (2007). The relationship between perceived employability and subsequent health. Work \& Stress, 21(3), 279-292.

Borg, I. \& Elizur, D. (1992). Job insecurity: Correlates, moderators and measurement. International Journal of Manpower, 13(2), 13-26.

Cheng, G. H. \& Chan, D. K. (2008). Who suffers more from job insecurity? A meta-analytic review. Applied Psychology: An International Review, 57(2), 272303.

Cheng, T., Mauno, S. \& Lee, C. (2014a). Do job control, support, and optimism help job insecure employees? A three-wave study of buffering effects on job satisfaction, vigor and work-family enrichment. Soc Indic Res, 118, 1269-1291.

Cheng, T., Mauno, S. \& Lee, C. (2014b). The buffering effect of coping strategies in the relationship between job insecurity and employee well-being. Economic and Industrial Democracy, 35(1), 71-94.

Cooper, C. L., Dewe, P. J. \& O'Driscoll, M. (2001). Organizational stress. Thousand Oaks: Sage.

De Goede, M. \& Maassen, G. (1988). Beleving van nietwerken: Een onderzoek onder werklozen, arbeidsongeschikten en hun partner. Culemborg/Amsterdam: University of Utrecht.

Dekker, S. W. A. \& Schaufeli, W. B. (1995). The effects of job insecurity on psychological health and withdrawal: A longitudinal Study. Australian Psychologist, 30(1), 57-63.

Demerouti, E. \& Bakker, A. B. (2011). The Job
Demands-Resources model: Challenges for future research. South African Journal of Industrial Psychology, 37, 1-9.

Demerouti, E., Bakker, A.B., Nachreiner, F., \& Schaufeli, W.B. (2001). The job demands-resources model of burnout. Journal of Applied Psychology, 86, 499-512.

De Witte, H. (1999). Job insecurity and psychological well-being: Review of the literatüre and exploration of some unresolved issues. European Journal of Work and Organizational Psychology, 8(2), 155-177.

De Witte, H. (2005). Job insecurity: Review of the international literature on definitions, prevalence, antecedents and consequences. South African Journal of Industrial Psychology, 31(4), 1-6.

Diener, E. (1984). Subjective well-being. Psychological Bulletin, 95, 542-575.

Dursun, B. \& Bayram, N., (2013). İş güvencesizliği algısının çalışanların kaygı düzeyleri üzerine etkisi: Bir uygulama. "İş, Güç" Endüstri İlişkileri ve İnsan Kaynakları Dergisi, 15(3), 20-27.

Edwards, J. R. (1988). The determinants and consequences of coping with stress. In C. L. Cooper \& R. Payne (Eds.), Causes, Coping, and Consequences of Stress at Work, 277-286. New York: Wiley.

Fatimah, O., Noraishah, D., Nasir, R. \& Khairuddin, R. (2012). Employment security as moderator on the effect of job security on worker's job satisfaction and well being. Asian Social Science, 8(9), 50-56.

Ferrie, J. E., Shipley, M. J., Marmot, M. G., Stansfeld, S. A. \& Smith, G. D. (1998). An uncertain future: The health effects of threats to employment security in white-collar men and women. American Journal of Public Health, 88, 1030-1036.

Gomez, C. (2003). The relationship between acculturation, individualism/collectivism, and job attribute preferences for Hispanic MBAs. Journal of Management Studies, 40, 1089-1104.

Greenhalgh, L. \& Rosenblatt, Z. (1984). Job insecurity: Toward conceptual clarity. Academy of Management Review, 9, 438-448.

Greenhalgh, L. \& Rosenblatt, Z. (2010). Evolution of research on job insecurity. International Studies of Management and Organization, 40(1), 6-19.

Hartley, J., Jacobson, D., Klandermans, B. \& van Vuuren, T. (1991). Job insecurity: Coping with jobs at risk. London: Sage.

Häusser, J. A., Mojzisch, A., Niesel, M. \& Schulz-Hardt, S. (2010). Ten years on: A review of recent research on the job-demand-control(-support) model and psychological well-being. Work \& Stress, 24, 1-35. 
Hellgren, J. \& Chirumbolo, A., (2003). Can union support reduce the negative effects of job insecurity on wellbeing? Economic and Industrial Democracy, 24(2), 271-289.

Hellgren, J. \& Sverke, M. (2003). Does job insecurity lead to impaired well-being or vice versa? Estimation of cross-lagged effects using latent variable modeling. Journal of Organizational Behavior, 24, 215-236.

Hellgren, J., Sverke, M. \& Isaksson, K. (1999). A twodimensional approach to job insecurity: Consequences for employee attitudes and well-being. European Journal of Work and Organizational Psychology, 8, 179-195.

Higgins, E. T. (1997). Beyond pleasure and pain. American Psychologist, 52, 1280-1300.

Hobfoll, S. E. (1989). Conservation of resources: A new attempt at conceptualizing stress. American Psychologist, 44, 513-524.

Hofstede, G. (1980). Culture's consequences. Beverly Hills, CA: Sage.

Hui, C. H. (1990). Work attitudes, leadership styles, and managerial behaviors in different cultures. In R.W. Brislin (Ed.), Applied cross-cultural psychology (186-208). Thousand Oaks, CA: Sage Publications.

Judge, T. A., Thoresen, C. J., Pucik, V., \& Welbourne, T. M. (1999). Managerial coping with organizational change: A dispositional perspective. Journal of Applied Psychology, 84, 107-122.

Karacaoğlu, K. (2015). Çalışanların iş güvencesizliğinin işten ayrılma niyetleri üzerindeki etkisi: Alanya bölgesindeki beş yıldızlı otellerde bir araştırma. Uluslararası Alanya Isşletme Fakültesi Dergisi, 7(1), 13-21.

Karasek, R.A. (1979). Job demands, job decision latitude, and mental strain: implications for job desiş güvencesizliğin. Administrative Science Quarterly, 24, 285-308.

Lazarus, R. S. \& Folkman, S. (1984). Stress, appraisal, and coping. New York, NY: Springer.

Lim, V. K. G. (1996). Job insecurity and its outcomes: Moderating effects of work-based and nonwork-based social support. Human Relations, 49(2), 171-194.

Mak, A. S. \& Mueller, J. (2000). Job insecurity, coping resources and personality dispositions in occupational strain. Work \& Stress, 14(4), 312-328.

Mantler, J., Matejicek, A., Matheson, K. \& Anisman, H. (2005). Coping with employment uncertainty: A comparison of employed and unemployed workers. Journal of Occupational Health Psychology, 10(3), 200-209.
Mauno, S., Ruokolainen, M., \& Kinnunen, U. (2013). Does aging make employees more resilient to job stress? Age as a moderator in the job stressor-wellbeing relationship in three Finnish occupational samples. Aging \& Mental Health, 17(4), 411-422.

McCrae, R. R. \& Costa, P. (1987). Validation of the fivefactor model of personality across instruments and observers. Journal of Personality and Social Psychology, 49, 710-721.

McKee-Ryan, F., Song, Z. \& Wanberg, C. R., \& Kinicki, A. (2005). Psychological and physical well-being during unemployment: A meta-analytic study. Journal of Applied Psychology, 90, 53-76.

Naswall, K., Sverke, M. \& Hellgren, J. (2005). The moderating role of personality characteristics on the relationship between job insecurity and strain. Work \& Stress, 19(1), 37-49.

Osipow, S. H. \& Spokane, A. R. (1987). Manual for the Occupational Stress Inventory. Odessa, FL: Psychological Assessment Resources.

Oyserman, D., Coon, H.M. \& Kemmelmeier, M. (2002). Rethinking individualism and collectivism: Evaluation of theoretical assumptions and metaanalyses. Psychological Bulletin, 128, 3-72.

Öztürk, E. B., Karagonlar, G. \& Emirza, S. (2016). Relationship between job insecurity and emotional exhaustion: Moderating effects of prevention focus and affective organizational commitment. International Journal of Stress Management. 24(3), 247-269.

Parkes, K. R. (1994). Personality and coping as moderators of work stress processes. Models, measures and methods. Work and Stress, 8, 110-129.

Paul, K. \& Moser, K. (2009). Unemployment impairs mental health: Meta-analyses. Journal of Vocational Behavior, 74, 264-282.

Poyraz, K. \& Kama, B. (2008). Algılanan iş güvencesinin, iş tatmini, örgütsel baglılık ve işten ayrılma niyeti üzerindeki etkilerinin incelenmesi, Süleyman Demirel Üniversitesi, Íktisadi ve İdari Bilimler Fakültesi Dergisi, 13(2), 143-164.

Probst, T. M. \& Lawler, J. (2006). Cultural values as moderators of employee reactions to job insecurity: The role of individualism and collectivism. Applied Psychology: An International Review, 55(2), 234254.

Richter, A., Naswall, K., Bernhard-Oettel, C. \& Sverke, M. (2014). Job insecurity and well-being: The moderating role of job dependence. European Journal of Work and Organizational Psychology, 23(6), 816-829.

Sandıkçı, E. (2009). İş güvencesizliğine karşı işçilerin 
kolektif tepkileri (Yayımlanmamış yüksek lisans tezi). Kocaeli Üniversitesi Sosyal Bilimler Enstitüsü, Kocaeli.

Sassenberg, K. \& Scholl, A. (2013). If I can do it my way ... The influence of regulatory focus on job-related values and job attraction. Journal of Economic Psychology, 38, 58-70.

Schaufeli, W. B., Salanova, M., Gonzalez-Roma, V. \& Bakker, A. B. (2002). The measurement of burnout and engagement: A confirmatory factor analytic approach. Journal of Happiness Studies, 3, 71-92.

Schreurs, B., Van Emmerik, H., Notelaers, G. \& De Witte, H. (2010). Job insecurity and employee health: The buffering potential of job control and job selfefficacy. Work \& Stress, 24(1), 56-72.

Schwartz, S. H. \& Bardi, A. (2001). Value hierarchies across cultures: Taking a similarities perspective. Journal of Cross-Cultural Psychology, 32, 268-290.

Selenko, E. \& Batinic, B. (2012). Job insecurity and the benefits of work. European Journal of Work and Organizational Psychology, 22(6), 725-736.

Shin, D. \& Johnson, D. (1978). Avowed happiness as an overall assessment of the quality of life. Social Indicators Research, 5(1), 475-492.

Shoss, M. K. (2017). Job insecurity: An integrative review and agenda for future research. Journal of Management, 43(6), 1911 -1939.

Silla, I., De Cuyper, N., Gracia, F. J., Peiro, J. M. \& De Witte, H. (2009). Job insecurity and well-being: Moderation by employability. Journal Happiness Study, 10, 739-751.

Stiglbauer, B. \& Batinic, B. (2015). Proactive coping with job insecurity: Is it always beneficial to well-being? Work \& Stress, 29(3), 264-285.

Stiglbauer, B., Selenko, E., Batinic, B. \& Jodlbauer, S. (2012). On the link between job insecurity and turnover intentions: Moderated mediation by work involvement and well-being. Journal of Occupational Health Psychology, 17(3), 354-364.

Sümer, N., Solak, N. \& Harma, M. (2013). İssiz yaşam: Isssizliğin ve iş güvencesizliğinin birey ve aile üzerindeki etkileri. [Unemployed life: Consequences of unemployment and job insecurity on individual and family]. Istanbul: Koç Üniversitesi Yayınları.

Sverke, M., Hellgren, J. \& Naswall, K. (2002). No security: A meta-analysis and review of job insecurity and its consequences. Journal of Occupational Health Psychology, 7(3), 242-264.

Triandis, H. C. (1995). Individualism and collectivism. Boulder, CO: Westview.
Türkiye İstatistik Kurumu (2018， Şubat). İșgücü istatistikleri, $\quad$ Ekim 2017. http://www.tuik.gov.tr/HbGetirHTML.do?id=27691

Van den Tooren, M. \& de Jong, J. (2014). Job demandsresources and employee health and well-being: The moderating role of contract type. Career Development International, 19(1), 101-122.

Wanberg, C. R. (2012). The individual experience of unemployment. Annual Review of Psychology, 63, 369-396.

Wang, H., Lu, C. \& Lu, L. (2014). Do people with traditional values suffer more from job insecurity? The moderating effects of traditionality. European Journal of Work and Organizational Psychology. 23(1), 107-117.

Watson, D. \& Clark, L. A. (1984). Negative affectivity: The disposition to experience aversive emotional states. Psychological Bulletin, 96, 465-490. 